\title{
Volker Henn
}

Volker Henn died unexpectedly from a heart attack on December 3, 1997 while he was returning home from a lecture. This is a great and untimely loss, not only for his family and the Neurological Department in $\mathrm{Zu}$ rich, but also to the international scientific community.

He was born on January 22, 1943 in Gotha (Germany) being the middle child of 5. His mother was a practising medical doctor and his father an architect. After finishing school in Braunschweig (Germany) he studied medicine in Munich, Vienna and Berlin. He wrote his thesis under the supervision of O.-J. Grüsser on Receptive-Field Properties of the Frog's Retina in Berlin, where he also completed his internship. From 1970 to 1971 he worked with Bernard Cohen at the Mount Sinai School of Medicine in New York. It was here that he started to investigate eye movement-related single unit activity in the brainstem of the behaving monkey, a topic which he pursued until the end. From New York he moved to Zurich (Switzerland) where he did his residency in Neurology under Günther Baumgartner. At the same time he built a laboratory for the study of central neuronal mechanisms of eye movement generation and the processing of vestibular information with

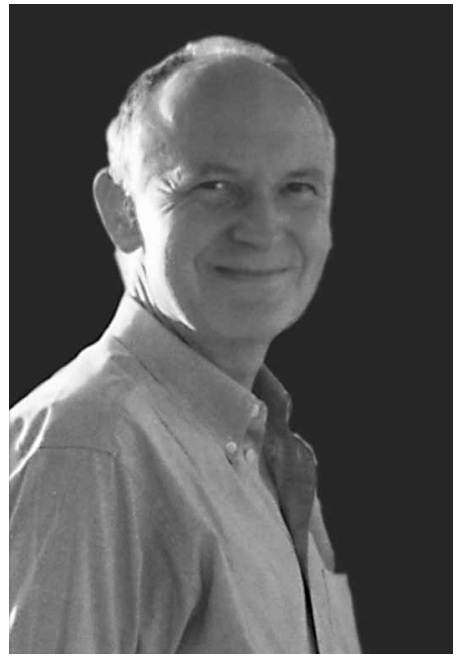

an emphasis on visual-vestibular interaction. With Larry Young and Walter Waespe he was the first to convincingly show in the primate that visual-vestibular interaction already takes place in the vestibular nuclei, only one synapse away from the vestibular nerve. Two of us (Büttner-Ennever and Büttner) had the privilege to determine with him the anatomical, physiological and clinical features of the rostral interstitial nucleus of the MLF, a brainstem structure important for vertical

\footnotetext{
KARGER

(c) 1998 S. Karger AG, Basel

Fax +4161306 1234

$\begin{array}{ll}\text { E-Mail karger@karger.ch } & \text { This article is also accessible online at: } \\ \text { www.karger.com } & \text { http://BioMedNet.com/karger }\end{array}$

http://BioMedNet.com/karge
} 
gaze. Later he extended his work to threedimensional aspects of sensory-motor transformation and had one of the best facilities worldwide to study these questions. Already in 1987 he organized with Bernard Cohen an international conference entitled 'Representation of Three-Dimensional Space in the Vestibular, Oculomotor and Visual Systems'.

One major goal of his research on animals was to relate the findings to normal and pathological findings in humans. With this in mind, he recently built a vestibular stimulator, with the support of the Betty and David Koester Foundation, for the investigation of canal-otolith interaction in humans, the construction being based on the latest technology and scientific results. This stimulator is close to completion and he was planning an international conference to celebrate its inauguration.

Beside his scientific work, he also always had a keen interest in general neurology and patient work. In 1984 he became Professor of Neurology. From 1990 to 1994 he was acting chairman of the Department of Neurology in Zurich. When Klaus Hess became the chairman of the department he had more time to spend with his lively research group.

In addition to his enormous scientific and clinical workload he had many other interests which he pursued energetically. He was an expert on the history of science, and loved books which filled many walls of his house. On his bicycle he preferred to climb mountains, he dived and visited many foreign countries, where he watched wildlife.

As a person he was an intellectual, a gentleman and a cosmopolitan. He was extremely knowledgeable in many fields and very supportive and generous to others, but he himself remained modest. He was loved by his many nieces and nephews and all his colleagues. Everyone who knew him, will miss him very much.

Munich, December 1997 Jean Büttner-Ennever Ulrich Büttner Thomas Brandt 